\title{
Assessment of Olive Pomace and Chicken \\ Manure Compared to Topsin-M70 in \\ Controlling Fusarium Wilt of Lupine with \\ Enhancement of some Yield Components \\ W.I. Shaban*; Heba M. Abd El-Nabi*; \\ M.A.S. El-Bramawy**; A.I. Mohamed $* * *$
}

* Agric. Botany Dept. Fac. Agric., Suez Canal Univ., Ismailia, Egypt.

** Agronomy Dept., Fac. Agric., Suez Canal Univ., Ismailia, Egypt.

*** Soils and Water Dept., Fac. Agric., Suez Canal Univ., Ismailia, Egypt.

Prganic wastes, a primarily by-products of many industrial
activities, include animal manures and olive pomace that were
used as compost. The compost-amended soils are the highly induced
suppression of numbers of soil-borne pathogens. Olive pomace and
chicken manure were used in this study compared to Topsin-M70 for
controlling lupine wilt disease caused by Fusarium oxysporum f.sp.
lupini under greenhouse and field conditions, Ismailia, Egypt.
In general, application of the two olive pomace and chicken manure
amendments suppressed Fusarium activity in both seasons (2008/09
and 2009/10) in comparison with Topsin-M70. Under greenhouse
conditions, the highest disease reduction ( $85.7 \%$ ) and the highest
percentage of healthy lupine plants ( $88 \%$ ) were recorded due to
treatment by olive pomace at the rate of $25 \%$ and chicken manure at
the rate of $10 \%$. On the other hand, olive pomace and chicken manure
compared to the fungicide Topsin-M70 caused a significant increase
in root length (RL), plant height (PH), number of branches/ plant
(NB), number of pods/plant (NP), and single yield plant (SYP) over
the control under green house conditions. The effect of olive pomace
and chicken manure on lupine wilt diseases incidence under field
conditions was positive, where, crop yields and its components, i.e.
PH, NB, NP and 100-seed weight (HSW) were increased in amended
plots. Generally, olive pomace and chicken manure enhanced fungal
pathogens suppressiveness and reduced the diseases incidence as well
as increased seed yield compared to the fungicide Topsin-M70.

Keywords: Chicken manure, damping-off, fungicides, Fusarium wilt, lupine, olive pomace and seed yield.

Lupines are annual or perennial herbs belonging to family Fabaceae. Lupine plants are susceptible to a number of plant diseases. Fusarium oxysporum Schlecht f.sp. lupini Snyder is a common fungal pathogen on lupine plants causing wilt disease resulting in serious economic losses. The main method of controlling crop diseases, which is followed in Egypt, is the direct application of fungicides. This management strategy is increasingly viewed as being ecologically undesirable and has led to an increased interest in the development and use of more ecologically sound integrated pest management practices such as biological control. In this respect, the current study describes a reduction in the use of chemical pesticide 
through the use of disease-suppressive compost. White lupine (Lupinus albus) has many benefits for human and animal nutrition. Its seed have a nutritional quality similar to soybean seed and superior to other legumes seed (Raza and Jrnsgard, 2005). Soilborne fungal diseases are among the most important factors limiting the yield production of legumes in many countries, resulting in serious economic losses. Pathogen such as $F$. oxysporum can has negative significant effects on the growth of lupine plants (Zian, 2005). Numerous studies have been published on the biological control of plant diseases (Hoitink and Fahy, 1986, El-Bramawy and El-Sarag, 2012) and on the use of composts to reduce disease in agricultural crops (Pera and Calvet, 1989 and Shaban et al., 2009). Ammonia and volatile organic acids released by decomposing organic matter killed Verticillium dahliae, and the residual organic matter stimulated competitive and antagonistic microorganisms in the soil. While these mechanisms suppressed the growth of $V$. dahliae, they may also create phytotoxicity to the plant roots, making them less attractive to colonization by the pathogen (Lazarovits et al., 2001). In this regard, Kotsou et al. (2004) found that addition of olive mill waste waters significantly suppressed growth of the root pathogen (Rhizoctonia solani). However, there is a lack of information on the long term effects of olive pomace and chicken manure compared to Topsin-M70 on crop yield and other populations of soil borne fungi under greenhouse/field conditions.

Therefore, this study aims to minimize the occurrence of lupine wilt as well as the possibility of measuring the extent of improvement and increase the yield and its components in the lupine plants by using two types of compost (olive pomace and chicken manure) compared to the fungicide Topsin-M70.

\section{Materials and Methods}

Fungal isolates:

Fusarium oxysporum was isolated from wilted lupine plants grown in Ismailia Governorate. It was microscopically identified on the basis of cultural and microscopic characteristics to the species level according to the descriptions of Nelson et al. (1983) and Lislie and Summerll (2006) and was confirmed in Assiut Univ., Mycol. Centre (AUMC). Pathogenicity of the isolate toward lupine plant was estimated (Sneh et al., 1991). The isolate was maintained on PDA medium at $4^{\circ} \mathrm{C}$. Artificial soil infestation by $F$. oxysporum grown on barley grain medium was carried out as described by Singleton et al. (1992).

Plant materials and experimental site:

Two lupine cultivars, i.e. Giza 2 (received from the Agric. Res. Centre, Food Legumes Res. Section, Giza, Egypt) and Mutant 7 (achieved by the Nuclear Res. Centre, Atomic Energy Authority in Egypt), were used as plant materials through this research. The category of both tested cultivars, Giza 2 and Mutant 7, as susceptible and resistance, respectively, was detected before in previous work carried out by Zian (2005). Greenhouse and field experiments were documented as experimental sites. These experiments were done at the Experimental Farm, Fac. of Agric., Suez Canal Univ. through two successive growing seasons (2008/09 and 2009/10).

Egypt. J. Phytopathol., Vol. 41, No. 1 (2013) 
Soil structure and compost analysis:

The soil of the experiments was sandy texture (94.8\% sand, $2.62 \%$ silt and 2.58 clay) with $\mathrm{pH}$ value of 7.67 , these figures were determined according to the method outlined by Kilmer and Alexander (1949). These estimates were carried out at the Soil and Water Department, Fac. of Agric., Suez Canal Univ., Ismailia. The chemical analysis of investigated soil after cropping included the chemical properties, electrical conductivity (EC), $\mathrm{pH}$, cations, anions and availability of NPK. Surface soil samples $(0-15 \mathrm{~cm})$ were taken prior to the application of treatments. The pretreatment samples comprised of a composite sample made up of 5 cores per experimental site. Soil samples were taken at the end of each planting season. The sample comprised of a composite sample of 2 cores per plot.

Treatments used in the experiment:

The effect of olive waste and chicken manure as natural substances compared to Topsin-M70 as chemical fungicide was investigated to test their effect on disease incidence under greenhouse and field conditions in both seasons.

Effect of olive waste, chicken manure and Topsin-M70 on the incidence of lupine wilt under greenhouse conditions:

Pots were prepared to study the effect of soil treatment with chicken manure and olive waste for controlling lupine wilt disease. A sterilized sorghum-seed medium was inoculated with the tested fungus, $F$. oxysporum and incubated at $25 \pm 2{ }^{\circ} \mathrm{C}$ for 15 days. Chicken manure and olive waste were composted for five weeks before incorporation into the potting mix. Pots $(30-\mathrm{cm}$-diam.) containing unsterilized soil were infested with the tested fungus at the rate of $3 \%(\mathrm{w} / \mathrm{w})$ of soil weight (El-Barougy, 2008). The infested soil was mixed thoroughly with compost treatments (chicken manure or olive waste at the rate of 5, 10 and $25 \%(\mathrm{v} / \mathrm{v})$, meanwhile, Topsin-M70 treatment was also prepared at the rate of $1 \mathrm{~g} / \mathrm{l}$. Topsin-M70 was applied in $50 \mathrm{ml}$ aliquots at planting and every $3 \mathrm{wk}$, thereafter of the 14 wk experiment (Wilson and Williamson, 2008). The pots were watered and kept for one week to ensure even distribution of the inoculum. Five lupine seeds/pot, either susceptible (cv. Giza 2) or resistant to Fusarium wilt (Mutant-7), were sown. Two control treatments, i.e. control (1) which is untreated seeds sown in infested soil as well as control (2) that is untreated seeds sown in non-infested soil, were used. Five pots were used for each treatment as a replicates. Early wilt and late wilt percentages were recorded one and three months after sowing, respectively. Whereas, survived lupine plants (healthy and infected) and disease severity were examined for visual wilt symptoms and internal tissue four months after sowing according to the modified scale, based on 0-4 grades of Ishikawa et al. (2005).

This experiment was carried out in a piece of land naturally infested by the causal of lupine wilt and root rot diseases prepared by El-Barougy and El-Sayad (2003) using only the susceptible cultivar Giza 2. The treatments were arranged in a randomized complete block design with three replicates. The sowing date was on 7 and 8 November during 2008/09 and 2009/10 growing seasons, respectively. The field plot was $3 \times 2 \mathrm{~m}^{2}$ with four rows; each row contained 10 hills on the eastern side. A hundred seeds (cv. Giza 2) were sown in each plot. Four treatments were followed and implemented in the following order: 
1. Olive waste (applied to the plot soil at the rate of $3 \mathrm{~kg} / \mathrm{m}^{2}$ at sowing).

2. Chicken manure (applied to the plot soil at the rate of $1 \mathrm{~kg} / \mathrm{m}^{2}$ at sowing).

3. Topsin-M70 (mixed through the soil prior to planting at the rate of $1 \mathrm{~g} / \mathrm{l}$ as recommended in soil drenching).

4. Untreated control.

Percentages of the late wilted and root-rotted plants as well as survived plants were recorded 30, 90 and 120 days after sowing, respectively.

Agronomic plant characters:

At harvest date (nearly after four months of planting), some of agronomic lupine plant characters, i.e. plant height $(\mathrm{cm})$, number of branches/plant, number of pods/plant, seed yield/plant (g) and root length/plant, were recorded. These characters were estimated, under greenhouse conditions, using the remained lupine plants in the pot. Meanwhile, under field conditions, characters of plants, i.e. plant height $(\mathrm{cm})$, number of branches/plant, number of pods/plant, 100-seed weight (gm), single plant yield $(\mathrm{gm})$ and seed yield/feddan $(\mathrm{kg})$, were estimated using five randomly selected lupine plants per/plot. However, number of days to flowering character was recorded, when $50 \%$ of the lupine plants were blooming.

Statistical analysis:

Analysis of variance (ANOVA) of the obtained data was performed by using the SAS statistical software (Version 6.311, Co. Hort.), Berkeley, CA 94701 (Anonymous, 1997). Least significant difference (LSD) was used to compare among means of the treatments (chicken manure, olive waste and Topsin-M70) over the two seasons. Probability levels lower than 0.05 or 0.01 were held to be significant (Gomez and Gomez, 1984). Also, data for yield and its components considering work under both conditions (field and greenhouse) throughout pathogens infestation, were taken into a count. The relations between both conditions through the studied characters including infection percentage were also integrated as a hub of hubs study.

\section{R e s u l t s}

Soil chemical analysis:

Chemical analysis of the soil after applying different concentrations of olive waste and chicken manure are presented in Tables (1 and 2). Chemical analysis showed an increasing in the soil content of salts, cations, anions, quantities of suitable nitrogen, phosphorus and potassium except sodium in the soil with the increasing of olive waste and chicken manure concentrations with different degrees.

Effect of olive pomace and chicken manure compared to the fungicide Topsin-M70 on controlling lupine wilt under greenhouse conditions:

Data in Table (3) indicate that all treatments (olive pomace, chicken manure and Topsin-M70) at any way concentrations decreased the percentages of wilted lupine plants after one and three months after sowing. While, the healthy survived plants were increased compared to the infested soil control (1). Data also pointed out that cv. Giza 2 grown in soil infested with $F$. oxysporum (control, 1) showed the highest disease severity score (2.8) and the lowest percentage of healthy survived plants 
Table 1. Chemical properties (Cations) of the soil amended with olive waste and chicken manure under greenhouse conditions after cropping, average of 2008/09 and 2009/10 seasons

\begin{tabular}{|l|c|c|c|c|c|c|}
\hline \multirow{2}{*}{\multicolumn{1}{c|}{ Treatment }} & EC & \multirow{2}{*}{$\mathrm{pH}$} & \multicolumn{4}{c|}{ Cations meql $^{-1}$} \\
\cline { 4 - 7 } & $\mathrm{dSm}^{-1}$ & & $\mathrm{Ca}$ & $\mathrm{Mg}$ & $\mathrm{Na}$ & $\mathrm{K}$ \\
\hline Control & 2.26 & 7.67 & 6.30 & 5.70 & 10.43 & 2.54 \\
\hline Olive waste 5\% & 3.01 & 7.62 & 7.80 & 6.30 & 12.50 & 2.65 \\
\hline Olive waste 10\% & 3.22 & 7.62 & 8.01 & 6.41 & 13.25 & 2.70 \\
\hline Olive waste 25\% & 3.84 & 7.60 & 8.69 & 7.91 & 15.98 & 3.21 \\
\hline Chicken manure 5\% & 4.26 & 7.60 & 12.25 & 8.32 & 11.44 & 3.25 \\
\hline Chicken manure 10\% & 6.28 & 7.55 & 16.85 & 10.64 & 11.21 & 4.16 \\
\hline Chicken manure 25\% & 15.85 & 7.51 & 22.15 & 13.81 & 1.84 & 5.91 \\
\hline Topsin-M70 & 2.26 & 7.67 & 6.30 & 5.70 & 10.43 & 2.54 \\
\hline
\end{tabular}

Table2. Chemical properties (Anions and available NPK) of the soil amended with olive waste and chicken manure under greenhouse conditions after cropping, average of 2008/09 and 2009/10 seasons

\begin{tabular}{|l|c|c|c|c|c|c|}
\hline \multirow{2}{*}{\multicolumn{1}{c}{ Treatment }} & \multicolumn{3}{c|}{ Anions meql $^{-1}$} & \multicolumn{3}{c|}{ Available $\mathrm{mgkg}^{-1}$} \\
\cline { 2 - 7 } & $\mathrm{HCO}_{3}$ & $\mathrm{Cl}$ & $\mathrm{SO}_{4}$ & $\mathrm{~N}$ & $\mathrm{P}$ & $\mathrm{K}$ \\
\hline Control & 5.83 & 9.73 & 9.29 & 3.14 & 1.86 & 11.73 \\
\hline Olive waste 5\% & 6.82 & 13.80 & 10.23 & 3.18 & 1.95 & 12.98 \\
\hline Olive waste 10\% & 7.22 & 15.23 & 11.59 & 4.12 & 2.11 & 13.80 \\
\hline Olive waste 25\% & 8.14 & 17.56 & 14.25 & 4.57 & 2.49 & 14.21 \\
\hline Chicken manure 5\% & 6.24 & 10.32 & 11.62 & 8.51 & 3.51 & 12.25 \\
\hline Chicken manure 10\% & 7.18 & 14.84 & 14.75 & 12.54 & 4.69 & 13.84 \\
\hline Chicken manure 25\% & 7.94 & 16.27 & 17.24 & 14.38 & 6.12 & 14.62 \\
\hline Topsin-M70 & 5.83 & 9.73 & 9.29 & 3.14 & 1.86 & 11.73 \\
\hline
\end{tabular}

(20\%) compared to the lowest disease severity score $(0.4)$ due treatment with olive waste and chicken manure. However, the highest disease reduction $(85.7 \%)$ was recorded when olive pomace at the rate of $25 \%$ and chicken manure at the rate of $10 \%$ were recorded, followed by chicken manure treatment at the rate of $5 \%$ $(0.60$ and $78.5 \%)$ for disease severity score and disease reduction, respectively. Moreover, the highest percentage of healthy lupine plants ( $88 \%$ ) was obtained due to treatment by olive pomace at the rate of $25 \%$ followed by each of chicken manure treatments/concentrations at the rate of 10 and $25 \%$ where both recorded $84 \%$ healthy survived lupine plants of cv. Giza 2, respectively. Meanwhile, the fungicide Topsin-M70 treatment recorded $60 \%$ healthy survived plants and disease reduction reached $64.3 \%$. Concerning Mutant-7 in Table (4), olive pomace at the rate of $25 \%$ and chicken manure at the rate of $10 \%$ treatments were the most effective treatments, judged by the lowest disease severity score (0.40) and the highest increase in disease reduction (80\%) compared to control-1 (Infested soil), which recorded disease severity score (2.0). In most cases, there were significant differences among the treatments and concentrations as well as soil infested with the wilt pathogen, $F$. oxysporum (control-1). Also, the same findings were observed between Topsin-M70 and the other treatments at the high rates. 
Table 3. Effect of olive waste and chicken manure compared to Topsin-M70 on wilt disease of cv. Giza 2 lupine plants under greenhouse conditions, an average of the two seasons $(2008 / 09$ and $2009 / 10)$

\begin{tabular}{|c|c|c|c|c|c|c|c|}
\hline \multirow{3}{*}{ Treatment } & \multirow{3}{*}{$\begin{array}{c}\text { Concentration } \\
(\mathrm{V} / \mathrm{V})\end{array}$} & \multicolumn{6}{|c|}{ cv. Giza 2 (Susceptible) } \\
\hline & & \multicolumn{2}{|c|}{ WP\%* } & \multicolumn{2}{|c|}{ SP\% } & \multirow{2}{*}{ DSS } & \multirow{2}{*}{$\mathrm{DR} \%$} \\
\hline & & $1 \mathrm{M}$ & $3 \mathrm{M}$ & IP\% & $\mathrm{HP} \%$ & & \\
\hline \multirow{3}{*}{ Olive waste } & $5 \%$ & 8 & 8 & 16 & 68 & 1.0 & 64.3 \\
\hline & $10 \%$ & 8 & 4 & 8 & 80 & 0.6 & 78.5 \\
\hline & $25 \%$ & 4 & 4 & 4 & 88 & 0.4 & 85.7 \\
\hline \multirow{3}{*}{$\begin{array}{l}\text { Chicken } \\
\text { manure }\end{array}$} & $5 \%$ & 8 & 4 & 12 & 80 & 0.6 & 78.5 \\
\hline & $10 \%$ & 8 & 0 & 8 & 84 & 0.4 & 85.7 \\
\hline & $25 \%$ & 4 & 8 & 4 & 84 & 0.6 & 78.5 \\
\hline Topsin-M70 & $1 \mathrm{~g} / \mathrm{l}(50 \mathrm{ml} / \mathrm{pot})$ & 0 & 8 & 32 & 60 & 1.0 & 64.3 \\
\hline Control (1) & ----- & 20 & 28 & 32 & 20 & 2.8 & - \\
\hline Control (2) & ----- & 8 & 8 & 12 & 72 & 1.0 & - \\
\hline L.S.D. at $0.05 \%$ & ----- & 3.30 & 3.05 & 9.68 & 10.29 & 0.74 & - \\
\hline
\end{tabular}

* $\mathrm{WP} \%=$ Wilted plants, SP\% $=$ Survived plants $\%, 1 \mathrm{M}=$ One month after seeding, $3 \mathrm{M}=$ Three months after seeding, IP = Infected plants $\%, \mathrm{HP}=$ Healthy plants $\%$, DSS $=$ Disease severity score, DR $=$ Disease reduction $\%$, Control $(1)=$ Untreated seeds sown in infested soil and control (2)= Untreated seeds sown in uninfested soil.

Table 4. Effect of olive waste and chicken manure compared to Topsin-M70 on wilt disease of $\mathrm{cv}$. Mutant 7 lupine plants under greenhouse conditions, an average of the two seasons (2008/09 and 2009/10)

\begin{tabular}{|l|c|c|c|c|c|c|c|}
\hline \multirow{3}{*}{ Treatment } & \multirow{2}{*}{$\begin{array}{c}\text { Concentration } \\
(\mathrm{V} / \mathrm{V})\end{array}$} & \multicolumn{6}{|c|}{ Mutant 7 (Resistant) } \\
\cline { 3 - 7 } & & \multicolumn{2}{|c|}{ WP\%* } & \multicolumn{2}{|c|}{ SP\% } & \multirow{2}{*}{ DSS } & \multirow{2}{*}{ DR\% } \\
\cline { 2 - 7 } & $5 \%$ & 4 & 8 & 16 & 72 & 0.8 & 60 \\
\hline \multirow{3}{*}{ Olive waste } & $10 \%$ & 8 & 4 & 8 & 80 & 0.6 & 70 \\
\cline { 2 - 7 } & $25 \%$ & 4 & 4 & 8 & 84 & 0.4 & 80 \\
\hline \multirow{3}{*}{ Chicken manure } & $5 \%$ & 8 & 4 & 12 & 76 & 0.8 & 60 \\
\cline { 2 - 7 } & $10 \%$ & 0 & 8 & 8 & 84 & 0.4 & 80 \\
\cline { 2 - 7 } & $25 \%$ & 4 & 4 & 8 & 84 & 0.4 & 80 \\
\hline Topsin-M70 & $1 \mathrm{~g} / \mathrm{l}(50 \mathrm{ml} / \mathrm{pot})$ & 4 & 0 & 36 & 60 & 0.8 & 60 \\
\hline Control (1) & ----- & 8 & 8 & 28 & 56 & 2.0 & - \\
\hline Control (2) & ----- & 4 & 4 & 8 & 84 & 0.8 & - \\
\hline L.S.D. at 0.05\% & ----- & 2.99 & 2.99 & 8.73 & 11.01 & 0.65 & - \\
\hline
\end{tabular}

* As described in footnote of Table (3).

Effect of olive pomace and chicken manure compared to the fungicide Topsin-M70 on the characters of lupine plants:

Data presented in Table (5) reveal that the application of olive pomace, chicken manure compared to Topsin-M70 as a fungicide caused a significant increase in plant height $(\mathrm{PH})$, number of branches/plant $(\mathrm{NB})$, number of pods/plant (NP), seed yield/plant (SYP) and root length (RL) over the control with the pathogen.

Egypt. J. Phytopathol., Vol. 41, No. 1 (2013) 
Table 5. Effect of olive waste and chicken manure compared to Topsin-M70 on some characters of cv. Giza 2 exposed to wilt under greenhouse conditions, an average of the two seasons (2008/09 and 2009/10)

\begin{tabular}{|c|c|c|c|c|c|c|}
\hline \multirow{2}{*}{ Treatment } & \multirow{2}{*}{$\begin{array}{c}\text { Concentration } \\
(\mathrm{V} / \mathrm{V})\end{array}$} & \multicolumn{5}{|c|}{ Giza 2 cultivar (Susceptible) } \\
\hline & & $\mathrm{PH}^{*}$ & $\mathrm{NB}$ & NP & SPY & $\mathrm{RL}$ \\
\hline \multirow{3}{*}{ Olive waste } & $5 \%$ & 65 & 6.6 & 13 & 10 & 45.5 \\
\hline & $10 \%$ & 72 & 6.8 & 13.2 & 13.5 & 44 \\
\hline & $25 \%$ & 77.4 & 8.9 & 16 & 17 & 46 \\
\hline \multirow{3}{*}{ Chicken manure } & $5 \%$ & 70 & 7.8 & 12 & 15 & 50 \\
\hline & $10 \%$ & 72.5 & 7.5 & 15 & 17 & 46 \\
\hline & $25 \%$ & 77.4 & 7.8 & 16 & 16.5 & 43.5 \\
\hline Topsin-M70 & $1 \mathrm{~g} / \mathrm{l}(50 \mathrm{ml} / \mathrm{pot})$ & 63.5 & 6.6 & 12 & 14 & 45 \\
\hline control (1) & \multirow{2}{*}{------- } & 43.2 & 5.7 & 7.2 & 8.6 & 23.3 \\
\hline control (2) & & 56.5 & 6.9 & 9.6 & 11.2 & 26.2 \\
\hline L.S.D at $0.05 \%$ & ------- & 6.68 & 0.68 & 1.53 & 2.44 & 1.69 \\
\hline
\end{tabular}

Also, results show that the lowest values of PH (cm), NB, NP, SPY (gm) and RL $(\mathrm{cm})$ of the lupine cv. Giza 2 were obtained from control-1, being $43.2 \mathrm{~cm}, 5.7$ branches/plant, 7.2 pods/plant, $8.6 \mathrm{gm} /$ plant and $23.3 \mathrm{~cm} /$ plant, respectively, (as a mean of five plants). Meanwhile, the greatest values of PH $(77.4 \mathrm{~cm}), \mathrm{NB}(8.9), \mathrm{NP}$ (16), SPY (17.0 gm) and RL (50.0) were recorded from lupine plants grown in infested soil by $F$. oxysporum and treated with olive pomace at the rate of $25 \%$ compared to the untreated lupine seeds, grown in uninfested soil, which recorded $56.5 \mathrm{~cm}(\mathrm{PH}), 6.9(\mathrm{NB}), 9.6(\mathrm{NP}), 11.2 \mathrm{gm}(\mathrm{SPY})$ and $26.2 \mathrm{~cm}(\mathrm{RL})$.

Concerning Mutant-7, data presented in Table (6) show that lupine plants grown in soil infested with $F$. oxysporum and treated with chicken manure at the rate of $25 \%$ recorded the highest values of plant height $(80.4 \mathrm{~cm})$, number of branches/plant (8.9), number of pods/plant (17), single plant yield (20.0 gm) and root length/plant $(50.3 \mathrm{~cm})$, followed by olive pomace treatment at the rate of $25 \%$ which recorded $78 \mathrm{~cm}(\mathrm{PH}), 7.9$ (NB), 16.6 (NP), 18.6gm (SPY) and $46.5 \mathrm{~cm} /$ plant (RL). While, the lowest values were obtained in case of control-1, being $61.6 \mathrm{~cm}, 6.8$ branches/plant, 10.4 pods/plant, $15 \mathrm{gm}$ and $40.4 \mathrm{~cm} /$ plant for $\mathrm{PH}, \mathrm{NB}, \mathrm{NP}, \mathrm{SPY}$ and RL, respectively.

Effect of olive pomace and chicken manure compared to the fungicide Topsin-M70 on controlling lupine wilt under field conditions:

The effect of olive pomace and chicken manure on lupine wilt and root-rot diseases complex incidence under field conditions through 2008/09 and 2009/10 growing seasons is shown in Table (7). Data show that the tested compost treatments reduced both of the lupine wilt and root-rot diseases. Meanwhile, the percentage of survived lupine plants was increased through season 2008/09 compared to the control (untreated). In the second season (2009/10), Topsin-M70 treatment recorded $95.7 \%$ survived plants, while it was $75.6 \%$ in control treatment. Generally, there were no significant differences among the treatments, but the differences were between the treatments and control, during both tested seasons. 
Table 6. Effect of olive waste and chicken manure compared to Topsin-M70 on some characters of cv. Mutant 7 exposed to wilt under greenhouse conditions, an average of the two seasons $(2008 / 09$ and $2009 / 10)$

\begin{tabular}{|l|c|c|c|c|c|c|}
\hline \multirow{3}{*}{ Treatment } & \multirow{2}{*}{$\begin{array}{c}\text { Concentration } \\
(\mathrm{V} / \mathrm{V})\end{array}$} & \multicolumn{5}{|c|}{ Mutant 7 (Resistant) } \\
\cline { 3 - 7 } & $5 \%$ & $\mathrm{PH}$ & $\mathrm{NB}$ & $\mathrm{NP}$ & $\mathrm{SPY}$ & $\mathrm{RL}$ \\
\hline \multirow{3}{*}{ Olive waste } & $10 \%$ & 74 & 7.5 & 12 & 16.5 & 45 \\
\cline { 2 - 7 } & $25 \%$ & 78 & 7.9 & 16.6 & 18.6 & 46.5 \\
\cline { 2 - 7 } & $5 \%$ & 68 & 6.3 & 14.2 & 17.6 & 46 \\
\hline \multirow{3}{*}{ Chicken manure } & $10 \%$ & 72 & 7.8 & 15 & 18 & 49.8 \\
\cline { 2 - 7 } & $25 \%$ & 80.4 & 8.9 & 17 & 20 & 50.3 \\
\cline { 2 - 7 } & $1 \mathrm{~g} / \mathrm{l}(50 \mathrm{ml} / \mathrm{pot})$ & 73.5 & 7.5 & 15 & 16.5 & 50.3 \\
\hline Topsin-M70 & - & 61.6 & 6.8 & 10.4 & 15 & 40.4 \\
\hline control (1) & ------ & 75.4 & 7.6 & 13.2 & 19.3 & 45.5 \\
\hline control (2) & ------- & 7.81 & 0.74 & 1.78 & 2.14 & 3.19 \\
\hline L.S.D at 0.05 \% & & & & & & \\
\hline
\end{tabular}

* As described in footnote of Table (5).

Table 7. Effect of olive waste and chicken manure compared to Topsin-M70 on wilt and root rot diseases of cv. Giza 2 lupine plants grown under field conditions during 2008/09 and 2009/10 growing seasons

\begin{tabular}{|c|c|c|c|c|c|c|}
\hline \multirow{3}{*}{ Treatment } & \multicolumn{3}{|c|}{ Season $2008 / 09$} & \multicolumn{3}{|c|}{ Season $2009 / 10$} \\
\hline & \multicolumn{2}{|c|}{ Infected plants (\%) } & \multirow[b]{2}{*}{$\begin{array}{l}\text { Survived } \\
\text { Plants }(\%)\end{array}$} & \multicolumn{2}{|c|}{ Infected plants (\%) } & \multirow{2}{*}{$\begin{array}{c}\text { Survived } \\
\text { Plants } \\
(\%)\end{array}$} \\
\hline & $\begin{array}{c}\text { Root-rotted } \\
\text { plants }\end{array}$ & $\begin{array}{l}\text { Wilted } \\
\text { plants }\end{array}$ & & $\begin{array}{c}\text { Root-rotted } \\
\text { plants }\end{array}$ & $\begin{array}{l}\text { Wilted } \\
\text { plants }\end{array}$ & \\
\hline Olive waste & 2.0 & 3.3 & 94.7 & 3.0 & 1.3 & 95.7 \\
\hline Chicken manure & 2.6 & 4.0 & 93.4 & 4.6 & 4.0 & 91.4 \\
\hline Topsin-M70 & 3.0 & 4.0 & 93.0 & 1.0 & 3.3 & 95.7 \\
\hline Control & 10.4 & 18.3 & 71.3 & 8.0 & 16.4 & 75.6 \\
\hline L.S.D. at $0.05 \%$ & 2.13 & 3.52 & 3.89 & 4.11 & 4.31 & 6.55 \\
\hline
\end{tabular}

Effect of olive pomace and chicken manure compared to the fungicide Topsin-M70 on some characters of lupine plants under field conditions:

The effects of olive pomace and chicken manure compared to Topsin-M70 fungicide on days to flowering (DF), plant height $(\mathrm{PH})$, number of branches /plant (NB), number of pods/plant (NP), 100-seed weight (HSW), single plant yield (SPY) and seed yield/feddan (SYF) of cv. Giza 2 lupine plants under field conditions through the two growing seasons, 2008/09 in Table (8) and 2009/10 in Table (9). All characters showed the highest values under the effect of olive pomace, followed by chicken manure, and at the same time exceeded the values of TopsinM70 and control treatments. The corresponding values are 70.6, 73.3 and 70.1, 75.2 for DF; 98.3, 96.5 and 102.3, 100.1 for PH; 8.9, 8.1 and 8.9, 8.5 for NB; 20.3, 18.4 and 22.1, 19.1 for NP; 45.1, 43.5 and 47.3, 45.1 for HSW; 37.2, 34.1 and 39.1, 34.9 for SPY and 1716.7, 1700 and 1733.4, 1683.4 for SYF for olive pomace, and chicken manure treatments during 2008/09 and 2009/10 seasons, respectively. In most cases no significant differences were detected between olive waste and chicken manure treatments. Topsin-M70 treatment showed significant differences in comparison with control treatment. 
Table 8. Effect of olive waste and chicken manure compared to Topsin-M70 on the characters of lupine plants cv. Giza 2 grown under field conditions during 2008/09 growing season

\begin{tabular}{|l|c|c|c|c|c|c|c|}
\hline \multirow{2}{*}{\multicolumn{1}{|c|}{ Treatment }} & \multicolumn{7}{c|}{ Season 2008/09 } \\
\cline { 2 - 8 } & DF* & PH & NB & NP & HSW & SPY & SYF \\
\hline Olive waste & 70.6 & 98.3 & 8.9 & 20.3 & 45.1 & 37.2 & 1716.7 \\
\hline Chicken manure & 73.3 & 96.5 & 8.1 & 18.4 & 43.5 & 34.1 & 1700.0 \\
\hline Topsin-M70 & 77.2 & 86.3 & 7.1 & 15.6 & 39.2 & 30.2 & 1600.1 \\
\hline Control & 79.3 & 72.6 & 5.3 & 10.5 & 30.2 & 19.6 & 600.1 \\
\hline L.S.D. at $0.05 \%$ & 1.5 & 4.5 & 0.6 & 1.6 & 2.5 & 2.9 & 206.1 \\
\hline L.S.D. at $0.01 \%$ & 4.6 & 13.9 & 1.8 & 5.1 & 7.8 & 9.1 & 633.6 \\
\hline
\end{tabular}

* $\mathrm{DF}=$ Days to flowering, $\mathrm{PH}=$ Plant height $(\mathrm{cm}), \mathrm{NB}=$ Number of branches/plant, $\mathrm{NP}=$ Number of pods/plant, HSW=100-seed weight $(\mathrm{gm}), \mathrm{SPY}=$ Single plant yield $(\mathrm{gm})$ and $\mathrm{SYF}=$ Seed yield/feddan $(\mathrm{kg})$.

Table 9. Effect of olive waste and chicken manure compared to Topsin-M70 on the characters of lupine plants cv. Giza 2 grown under field conditions during 2009/10 growing season

\begin{tabular}{|l|c|c|c|c|c|c|c|}
\hline \multirow{2}{*}{ Treatment } & \multicolumn{7}{|c|}{ Season 2009/10 } \\
\cline { 2 - 8 } & DF* & PH & NB & NP & HSW & SPY & SYF \\
\hline Olive waste & 70.1 & 102.3 & 8.9 & 22.1 & 47.3 & 39.1 & 1733.4 \\
\hline Chicken manure & 75.2 & 100.1 & 8.5 & 19.1 & 45.1 & 34.9 & 1683.4 \\
\hline Topsin-M70 & 76.4 & 90.1 & 7.6 & 17.4 & 41.3 & 32.5 & 1666.7 \\
\hline Control & 78.9 & 73.6 & 5.2 & 11.9 & 28.9 & 20.1 & 716.7 \\
\hline L.S.D. at 0.05 \% & 1.4 & 4.9 & 0.6 & 1.3 & 3.4 & 3.1 & 187.3 \\
\hline L.S.D. at 0.01 \% & 4.4 & 15.4 & 1.9 & 5.1 & 10.4 & 9.6 & 576.2 \\
\hline
\end{tabular}

* As described in footnote of Table (8).

\section{D i s c u s s i o n}

Organic wastes, primarily by-products of many industrial activities, include animal manures and olive pomace. To reduce the environmental contamination, it is essential to use the organic wastes as an important resource in biological control programs. Possible utilization of organic wastes includes their use as a fertilizer and soil amendment. One of the beneficial properties of compost-amended soils is the highly induced suppression of numbers of soil-borne pathogens, such as Pythium spp., Phytophthora spp., Rhizoctonia spp. and Fusarium spp. In addition, D'Addabbo et al. (2003) studied the possibility of using olive pomace and chicken manure amendments for control of Meloidogyne incognita over two crop cycles. They found that the combination of olive pomace with chicken manure enhanced suppressiveness and increased crop yield compared to the single amendments alone.

Della Greca et al. (2001) and Isidori et al. (2005) reported the inhibition of plant and microbial growth by low-molecular-weight phenols present in olive mill wastes. Meanwhile, Aziz et al. (1998) observed that high-molecular-weight polyphenols 
such as oleuropein or lignin-like polymers have shown a toxic activity produced in olive wastes. However, hydroxytyrosol has been identified as one of the major natural phenolics present in olive mill wastes (Fiorentino et al., 2003). In addition, Del-Río et al. (2003) suggested that phenolic compounds were involved in the defence mechanisms of olive plants against Phytophthora sp., with tyrosol being the most active agent, followed by catechin and oleuropein and leading to greater suppression.

The results of the present investigation are in agreement with those obtained by Aryantha et al. (2000) who showed that the addition of fresh or composted chicken manure to potting mix significantly reduced the survival of Phytophthora cinnamomi and the development of disease in lupine seedlings. They also found that chicken manure increased soil organic matter, total biological activity and populations of antagonistic Actinomycetes, Pseudomonas fluorescent and fungi. However, chicken manure also stimulated the production of endospore-forming bacteria, which were positively correlated with lupine plant survival. Also, Bello et al. (2002) mentioned that olive remains as biofumigation material were as effective as conventional pesticides in the control of root-knot nematodes, fungi, insects and weeds.

Results of the present study indicated that soil chemical analysis, after amended with the olive waste and chicken manure, showed an increase in the content of salts, cations and anions quantities of suitable nitrogen, phosphorus and potassium except sodium in the soil with the increase of chicken manure concentration in the soil. In this regard, Adeleye et al. (2010) found that increasing rates of added plant residues and chicken may be due to increased concentration of calcium and magnesium is either to lower sodium concentration in the soil to the ability of calcium to the expulsion of sodium from the soil replacement and replaced it.

Application of olive pomace or chicken manure caused a significant increase in growth parameters of lupine cv. Giza 2 grown in infested soil with $F$. Oxysporum, compared to the fungicide Topsin-M70. The greatest values of plant height (PH), number of branches (NB), number of pods (NP), 100-seed weight (HSW) and root length (RL) were recorded from lupine plants grown in infested soil and treated with olive pomace at the rate of $25 \%(\mathrm{v} / \mathrm{v})$ compared to untreated lupine seeds grown in non- infested soil (control 2). These results may be due to that the waste content of total dissolved salts was low compared to chicken residues which are relatively high. Chicken waste contained the high nitrogen, phosphorus and potassium contents compared to the olive residues. Also, it showed the high content of calcium and magnesium compared to the sodium concentration in the chicken waste. This finding and its inquiries depend on the chemical analysis of olive waste and chicken manure presented in Table (1 and 2). In this connection, D'Addabbo et al. (2003) reported that fresh and exhausted olive pomace as organic amendments had significant nematicidal effects on root-knot nematodes and increased tomato yields in Italy. In regarding to Mutant-7, chicken manure treatment at the rate of $25 \%(\mathrm{v} / \mathrm{v})$ recorded the highest values of plant growth and yield components followed by olive pomace treatment. Many studies reported that fertilizing power of organic fertilizers is due to their content of stabilized organic matter and due to their component of 
nutrient elements (Bevacqua and Mellano, 1993). These results are in accordance with those obtained by El-Morshedy (1997) who found that using chicken manure increased shoot growth rate, leaf area and percentage of leaves and dry weight of sour orange seedlings. Results are also agree with those of Helail et al. (2003) who reported that shoot on different growth cycles of Washington navel orange. Also, these findings are in harmony with those of by Igua et al. (2008) who reported that plant height, grain yield and selected yield components of maize gave positive responses to chicken manure application.

Data of field experiments showed that the tested compost treatments reduced lupine wilt and root-rot diseases and increased the percentage of the lupine survived plants compared to the control. The highest percentage of survived plants was recorded due to olive pomace treatment with the highest values of seed yield weight during the first and the second seasons. These findings, that resulted by applying organic fertilization, may be attributed to the stimulation effect of the absorbed nutrients on photosynthesis process, also, the slow release nutrients resulting from the biodegradation of manure by soil microorganisms could explain the present results (Cole et al., 1987 and Bhangoo et al., 1988). In this regard, the enhancement of decrease of wilt and root-rot diseases incidence with increasing the seed yield and its attributes characteristics could be attributed to the capability of soil microorganisms to produce growth regulators such as auxins, cytokinines and gibberellins which had a positive effect on flowering process and nutrients uptake (Martin et al., 1989). Also, these results are in conformity with those obtained by Kotsou et al. (2004) who found that addition of olive mill waste significantly suppressed root rot disease incidence caused by $R$. solani. The increase in yield and its components might be attributed to the relatively high content of minerals and or elements in olive pomace and chicken manure in the lupine plants, which grown in the greenhouse and under field conditions. The same results were reported by El-Morshedy (1997), Hegazi et al. (2007), Fayed (2005 and 2010).

\section{Ref e r e n c e}

Adeleye, E.O.; Ayeni, L.S. and Ojeniyi S.O. 2010. Effect of chicken manure on soil physico-chemical properties, leaf nutrient contents and yield of yam (Dioscorea rotundata) on alfisol in South-western Nigeria. J. Amer. Sci., 6(10): 871-878.

Anonymous. 1997. SAS Institute, SAS/STAT User`s Guide: Statistics. Ver. 6.12, SAS Institute Inc., Cary, NC.

Aryantha, I.P.; Cross, R. and Guest, D.I. 2000. Suppression of Phytophthora cinnamomi in potting mixes amended with uncomposted and composted animal manures. Phytopathology, 90: 775-782.

Aziz, N.H.; Farag, S.E.; Mousa, L.A.A. and Abo-Zaid, M.A. 1998. Comparative antibacterial and antifungal effects of some phenolic compounds. Microbios, 93: 43-54. 
Bello, A.; Lopez-Perez, J.A. and Alvarez, A.G. 2002. Biofumigation as alternative to Methyl Bromide. Proc. Annual Internat. Conf. on Alternatives to Methyl Bromide "The Remaining Challenges", Sevilla, Spain.

Bevacqua, R.F. and Mellano, V.J. 1993. Sewage sludge compost accumulative effects on crop growth and soil properties. Compost Sci. Util., 1: 34-37.

Bhangoo, M.S.; Day, K.S.; Sualanagunta, V.R. and Petrucet, V.E. 1988. Application of chicken manure influence on Thompson seedless grape production and soil properties. Hortscience, 23: 1010-1012.

Bloomberg, W.J. 1981. Disease caused by Fusarium in forest nurseries. Pages: 178-187. In: Fusarium: Diseases, Biology and Taxonomy. Nelson, P.E.; Tousson, T.A. and Cook, R.J. (eds.). The Pennsylvania State University Press. Penn., USA.

Cole, C.V.; Williams, J.M. and Hanson, J. 1987. Nutrients and organic matters as components of agricultural production system models. SSSA Spec. Madison, WI, 19: $147-166$.

D’Addabbo, T.; Sasanelli, N.F.; Lamberti, P. and Carella. A. 2003. Olive pomace and chicken manure amendments for control of Meloidogyne incognita over two crop cycles. Nematropica, 33: 1-7.

Del-Río, J.A.; Báidez, A.G.; Botía, J.M. and Ortuño, A. 2003. Enhancement of phenolic compounds in olive plants (Olea europaea L.) and their influence on resistance against Phytophthora sp. Food Chem., 83: 75-8.

Della Greca, M.; Monaco, P.; Pinto. G.; Pollio, A; Previtera, L. and Temussi, F. 2001. Phytotoxicity of low-molecular-weight phenols from olive mill waste waters. Bull Environ. Contam. Toxicol., 67: 352-9.

El-Barougy, Ebtihag S.H. and El-Sayad, Z.S. 2003. Evaluation of four microbial products as compared with fungicide for controlling Fusarium wilt of Lupinus albus. Egypt. J. Appl. Sci., 18: 69-83.

El-Barougy, Ebtihag, S.H. 2008. Effect of using mustard (Brassica juncea) as biofumigation on controlling some soil borne fungal pathogens in chickpea plants. Egypt. J. Appl. Sci., 32: 74-93.

El-Bramawy, M.A.S. and El-Sarag, E.E. 2012. Enhancement of seed yield and its components in some promising sesame lines using antagonism of Trichoderma spp. against soil-borne fungal diseases, Internat. J. Forest, Soil and Erosion, 2(3): 148-154.

El-Morshedy, F.A. 1997. Organic manure and sulphur interaction influence vegetative growth and element concentration of sour orange seedlings. J. Agric. Sci., Mansoura Univ., 22: 4599-4614.

Fayed, T.A. 2005. Response of desert red peach trees to organic and some biofertilizers in comparison with chemical fertilizer. Egypt. J. Appl. Sci., 20: $127-143$. 
Fayed, T.A. 2010. Response of four olive cultivars to common organic manures in Libya. American-Eurasian J. Agric. \& Environ. Sci., 8(3): 275-291.

Fiorentino, A.; Gentili, A.; Isidori, M.; Monaco, P.; Nardelli, A. and Parrella, A. 2003. Environmental effects caused by olive mill wastewaters: toxicity comparison of low-molecular-weight phenol components. J. Agric. Food Chem., 51: 1005-1009.

Gomez, K.A. and Gomez, A.A. 1984. Statistical Procedures for Agricultural Research, $2^{\text {nd }}$ Ed. John Wiley and Sons, NY, USA. 680pp.

Hegazi, E.S.; El-Sonbaty, M.R.; Eissa, M.A. and El-Sharony, T.F.A. 2007. Effect of organic and bio-fertilization on vegetative and flowering of Picual olive trees. World J. Agric. Sci., 3: 210-217.

Helail, B.M.; Gobran, Y.N. and Moustafa, M.H. 2003. Study on the effect of organic manure source, method of organic manure application and biofertilizers on 1- tree growth and leaf mineral content of Washington navel orange trees. Egypt. J. Appl. Sci., 18: 297-320.

Hoitink, H.A.J. and Fahy, P.C. 1986. Basis for the control of soilborne plant pathogens with composts. Annu. Rev. Phytopathol. 24: 93-114.

Igua, P.; Kanehito, S.; Binifa, J. and Ewande, M. 2008. Correlation of topography to selected soil and plant variables on UOG Farm. A poster presentation at the Science and Technology Conf., Univ. Goroka, Papua New Guinea.

Ishikawa, R.; Shirouzu, K.; Nakashita, H.; Lee, H. Y.; Motoyama, T.; Yamaguchi, I.; Teraoka, T. and Arie, T. 2005. Foliar spray of vlidamycin A or validoxylamine A controls tomato Fusarium wilt. The Amer. Phytopathol. Soc., 95: 1209-1216.

Isidori, M.; Lovorgna, M. ; Nardelli, A. and Parrella, A. 2005. Model study on the effect of 15 phenolic olive mill wastewater constituents on seed germination and Vibrio fischeri metabolism. J. Agric. Food Chem., 53(21): 8414-8417.

Kilmer, V.J. and Alexander, L.T. 1949. Methods of making mechanical analysis of soils. Soil Sci. 68:15-24.

Kotsou, M.; Mari, I.; Lasaridi, K.; Chatzipavlidis, I.; Balis, C. and Kyriacou, A. 2004. The effect of olive oil mill wastewater (OMW) on soil microbial communities and suppressiveness against Rhizoctonia solani. Appl. Soil Ecol., 26: 113-121.

Lazarovits, G.; Tenuta, M. and Conn, K.L. 2001. Organic amendments as a disease control strategy for soilborne diseases of high-value agricultural crops. Austral. Plant Pathol., 30: 111-117.

Lislie J.F. and B.A. Summerll (2006). The Fusarium-Laboratory Manual. Blackwell Publishing. 388pp. 
Martin, P.; Galatzly, A. Klob, W. Omayand, H. and Shmdidt, W. 1989. Nitrogen fixing bacteria in the rhizosphere quantification and hormonal effects on root development. Z. Pflonzyernahr Boodenk., 152: 237-245.

Nelson, P.E.; Toussoun, T.A. and Marasas, W.F.O. 1983. Fusarium Species: An Illustrated Manual for Identification. Pennsylvania State Univ. Press, Univ. Park, Penn., USA.

Pera, A. and Calvet, C. 1989. Suppression of Fusarium wilt of carnation in a composted pine bark and a composted olive pomace. Plant Dis., 73: 699-700.

Raza, S. and Jrnsgard, B. 2005. Screening of white lupine accessions for morphological and yield traits. African Crop Sci. J., 13 (2): 135-141.

Shaban, W.I.; El-Marzoky, H.A. and Mohamed, A.I. 2009. Suppression of Rhizoctonia solani root rot on strawberry plants by using biological control strategy. $6^{\text {th }}$ Internat. Plant Breeding Conf., Ismailia, Egypt.

Singleton, L.; Mihail, J. and Rush, C. 1992. Methods for Research on Soil-Borne Phytopathogenic Fungi. The Amer. Phytopathol. Soc., St. Paul, Minnesota, USA. 266pp.

Sneh, B.; Lee, B. and Akira, O. 1991. Identification of Rhizoctonia species. The Amer. Phytopathol. Soc., St. Paul, Minnesota, USA.129pp.

Wilson G.W.T. and Williamson M.M. 2008. Topsin-M: the new benomyl for mycorrhizal-suppression experiments. Mycologia, 100: 548-554.

Zian, A.H. 2005. Studies on lupine root rot and wilt diseases. M.Sc. Thesis, Fac. of Agric., Suez Canal Univ., Egypt. 142pp.

(Received 17/04/2013;

in revised form 21/05/2013) 
تقييم دور تفل الزيتون وسماد مخلفات

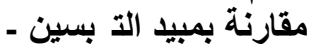

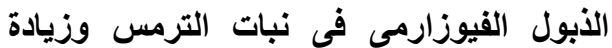

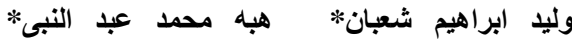

$$
\begin{aligned}
& \text { محمد عبد الحميد }
\end{aligned}
$$

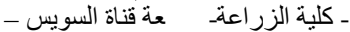

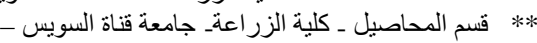

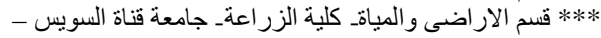

المخلفات العضوية وبخاصة المنتجة من الانشطة الصناعية او الزراعية مثل المخلفات الحيوانية وتفل الزيتون تستخدم كاسمدة زلية زراعية.

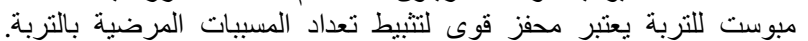
فى هذه الدراسة تم استخدام تفل الزيتون وسماد مخلفات الدواجن مقارنة بمبيد

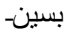

Fusarium oxysporum f.sp. lupini

نجح كل من تفل الزيتون وسماد مخلفات الدواجن محافظة الاسماعيلية

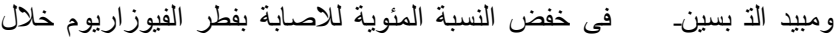
I

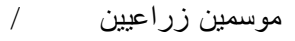

$\%$

ليمة بنسبة \% تم تسجيلها عند معاملات التسميد وبخاصة تركيز

\% لتفل الزيتون و \%

ومن جهة اخرى ادى تفل الزيتون وسماد مخلفات الدواجن مقارنة بمبيد

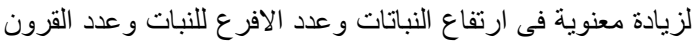

فقد ادت المعاملات الى حدوث ناثير

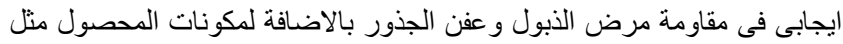

بستطيع تفل متل

الزيتون وسماد مخلفات الدو اجن تثبيط الفطريات الممرضة بالثربة وخفض حدوث المرض بالاضافة لزيادة 